\title{
Reflection of Nations Mentality in the Kyrgyz, Russian and English Language Phraseological Units
}

\section{Oktomkan Mamasheva1, Gulipa Madmarova², Gulsana Abytova3 ${ }^{3}$, Baktygul Berdibekova ${ }^{4}$, Gulzat Bolotakunova ${ }^{2}$, Rahat Ormokeeva ${ }^{5}$, Aiburak Shaimkulova² ${ }^{2}$, Ykybal Temirkulova ${ }^{2}$, Zhypargul Abdullaeva ${ }^{*}$ (1)}

${ }^{1}$ Department of Foreign Languages, Osh State University, Osh, Kyrgyzstan

${ }^{2}$ Department of Russian Language Practical Course and Speech Culture, Osh State University, Osh, Kyrgyzstan

${ }^{3}$ Department of World Literature, Osh State University, Osh, Kyrgyzstan

${ }^{4}$ Department of American Studies and Translation, Osh State University, Osh, Kyrgyzstan

${ }^{5}$ Department of Russian Language, Osh State University, Osh, Kyrgyzstan

${ }^{6}$ Science and Research Department, Osh State University, Osh, Kyrgyzstan

Email: ${ }^{\star}$ jypar.science@oshsu.kg

How to cite this paper: Mamasheva, O., Madmarova, G., Abytova, G., Berdibekova, B., Bolotakunova, G., Ormokeeva, R., Shaimkulova, A., Temirkulova, Y., \& Abdullaeva, Z. (2021). Reflection of Nations Mentality in the Kyrgyz, Russian and English Language Phraseological Units. Open Journal of Modern Linguistics, 11, 24-33. https://doi.org/10.4236/ojml.2021.111002

Received: December 20, 2020

Accepted: January 17, 2021

Published: January 20, 2021

Copyright $\odot 2021$ by author(s) and Scientific Research Publishing Inc. This work is licensed under the Creative Commons Attribution International License (CC BY 4.0).

http://creativecommons.org/licenses/by/4.0/

\begin{abstract}
The article compares phraseological words and their equivalents in the Kyrgyz, Russian and English languages by examples from those people worldviews, life outlooks, and environmental perceptions depending on their lifestyle. In most cases, phraseological units are not translated directly into another language, so only their equivalents can be found in other languages. Here, examples of regular expressions of the same meaning in each language specific to that people have been found and compared. Particular attention was made to the emergence of idioms in language and their analysis. The relevance in this work is to compare national and cultural experience through the phraseological units in the Kyrgyz, Russian and English languages due to insufficient research results. The purpose of this study is to introduce readers with the formation of regular phraseological expressions based on the lifestyles of the above mentioned people, and their equivalents in Kyrgyz, Russian and English languages. The practical implication is the existence of equivalents reflected customs and habits of the above mentioned people since phraseologies are not translating verbally.
\end{abstract}

\section{Keywords}

Typology, World Picture, Representation, Phraseology, Equivalent, Specificity, Perception, Position, Conventional Translation 


\section{Introduction}

The content of phraseological units, the reality of life in their meanings, and phenomena are closely linked with the nation's outlook on the picture of the world. In the picture of the world of each ethnic group, there are basic concepts that are especially important for that nation. For each nation, the way of conceptualizing the truth is universal and national. Therefore, we can say that people who speak different languages see the world through the prism of their own language. The linguistic picture of the world of nations depends on many factors. Studying the phraseological units, we conclude that the lifestyle and geographical location of the country are of special importance for the linguistic picture of the world. Language learning research (LLR) is focused on the analysis of links between fundamental cognitive meanings in language learning and their use in different kinds of situations, storage, representation, and access to these units in the mental lexicon (Gablasova et al., 2017).

The Russian phraseology meanings and interpretations based on the endless forests, steppes, and wide rivers on the Russian land reflecting the Russian people's breadth, courage, and character. The British people live on an island surrounded by the sea, the boundaries of which seems to be limiting them, and it is safe to say that the British a restrained, and well-mannered people. The Kyrgyz people experienced a nomadic lifestyle, which made them lack a certain degree of accuracy, but at the same time to love freedom and courage.

Expansion of diplomatic relations, education culture, and trade relationships with foreign countries, resulting in the necessity to study the English phraseological units (Azizova et al., 2020). Most of the English phraseology is associated with the sea, fishing boats, and so on. Kyrgyz phraseological units are full of concepts related to animal husbandry and the basic nature of life. Russian phraseological units reflect different aspects of life and allow different realities because the geography and way of life are associated with the seas, livestock, and agriculture.

Research process in this work focused on phraseological units in the Kyrgyz, Russian and English languages and their meanings. Research materials in this study were phraseological units in Kyrgyz, Russian and English languages, their meanings and equivalents. Research methods were based on description, comparing and analysis of various phraseological units and phrases with their equivalents in above mentioned languages.

\section{Phraseology Definitions}

Phraseology (from Greek phrasis means expression, logos is science) is the branch of knowledge in linguistic unity, the structure of which is complex and stable. Phraseology is also defined as a knowledge of formulaic sequences or multi-word expressions, several definitions were determined, such as "matching a single meaning or function to a form, although that form consists of multiple orthographic or phonological words" (Kremmel et al., 2017). Phraseology is a 
means of expressing an idea in a beautiful, clear, and imaginative way, creating an integral whole, consisting of regular expressions, and ready-made in speech. Phraseological words in any language are the best linguistic means of that language. Sometimes it is not easy to determine the source of phraseology. But, once their meaning is known, it's even more interesting to know where they came from. Phrasal verbs have been used since the dawn of time, embodying the centuries-old experience of the people and inherited from generation to generation.

Therefore, regular expressions in any language are the best linguistic means of that language. Phraseologisms are a living testimony of the past. Therefore, knowing the history of their origin enriches our minds. Phraseological words are used in the figurative sense of the word. Often it is not possible to translate them directly into other languages, because the meanings are based on national characteristics. They can only have equivalents in another language. Similarly, phraseological expressions are a valuable tool in the study of the country due to visible ethnolinguistic components. The first study of phraseology in general linguistics belongs to the Swiss scholar C. Bally (Pym, 2014), his work named "French Stylistics" published in 1901, which was known to the Russian linguists after its translation in 1905.

\section{Russian, English and Kyrgyz Phraseology}

The most important work on phraseology in Russian linguistics belongs to V.V. Vinogradov. His speech at a scientific session in Leningrad in 1946 on "Basic concepts of Russian phraseology as a linguistic discipline" is known in history as a major breakthrough in linguistics. He noted that although there have been several studies on phraseology in the previous linguistic literature, phraseology has been considered only in the context of lexicology, further this unit of language has been studied as a separate branch of linguistics, emphasizing that phraseology should be recognized as a branch of linguistics. Regarding the Russian language phraseology, many scientists' works are known such as professor N.M. Shansky's work "Phraseology of modern Russian language", professor V.P. Zhukov's work "On the question of the polysemy of phraseology", and "Semantics of phraseological conversations", professor A.I. Molotkov's book published in 1977 "Basic Russian Phraseology", occupying a special place (Ivanova, 2018).

The English language is spoken by 400 million people and is considered as a mother tongue worldwide internationally, where phraseological units play an integral part of the language (Beshaj, 2014). English language phraseology represents significant interest in the development of linguistics theory (Nikulina, 2017). Phraseological units (PU) in the English language were selected with the help of idiom dictionaries, for example, Collins COBUILD Dictionary of Idioms, Oxford Idioms Dictionary for Learners of English, Chambers English Dictionary of Idioms, Cambridge International Dictionary of Idioms and Dictionary of Idioms and their Origins (Vrbinc \& Vrbinc, 2014). 
First Kyrgyz language phraseology works were conducted by researcher A. Shukurov. His article named "On phraseological combinations in the Kyrgyz language" was published in 1956. Many articles have been published on phraseology in both general linguistics and Turkology. Phraseological idioms were studied in detail, as a result, phraseology became a branch of the linguistic study of the language and regular expressions. The study objects have been clarified by Shukurov Z., Osmonova Z., Mamytov Z., Mukambaev Z., Suranchieva Z., Nazarov, A., Chymynov Z., Toskonalieva R., Egemberdiev R., and others. This part in our language is still being studied scientifically, theoretically, practically, and methodologically. For example, the "Phraseological dictionary of the Kyrgyz language" was supplemented again in 2001 by Osmonova Z., Konkobaev K., Zhaparov (2015), which contains 7980 regular phraseological expressions (Israilova, 2017).

The phraseology of each nation depends on the lifestyle and location of that nation. For example, the Kyrgyz land is mountainous and the people are engaged in animal breeding, their world sense and worldview are connected with animal farming. When the Kyrgyz people ask about each other, they asked: "Are your animals and your health safe?", they first ask about their animals, and then about health. After all, almost all their livelihood depended on animal farming. The Kyrgyz people lived in nomadic life and spend winter in wintering, and from spring were in the jailoo (summer pasture). Their main occupation was animal breeding. The horse is a versatile animal for nomads, as a carrier, a hunter, a butcher, and a participant in various games (blue wolf, horseracing, etc.). Therefore, the phrase "Ат, аттан кийин жат" which means "First is taking care of the horse, rest is after" used commonly.

\section{Phraseological Unit Reflections}

Lifestyle, history and worldview of the Kyrgyz people can be seen from the phrase “Конок бир күн консо кут, эки күн консо жут" which means, "A guest can eat one day, the second day is a hunger". This phraseology includes the Kyrgyz people's hospitality and animal farming lifestyle. The word "кут" means happiness, success, and prosperity, and the word "жут" means the death of an animal due to the lack of feed (Seydakmatov, 1988).

Kyrgyz people are naturally friendly people, despite any situation, they try to meet guests well. Even they experienced a nomadic lifestyle, they appreciated guests and friendship. When visitors come on horseback, the host asks them, "What kind of grass does your horse chew?", and the guest says, "My horse chews clover grass," or "My horse chew dried grass." In this regard, the horses were taken care of and tied separately.

It is an ancient tradition to cut a horse with a bone for a guest. Ustukan (sheep, horse or cow meat with bone) is presented to the guests according to age, the importance of the guest to the expectant family, namely meat with bone is kept in order and presented to older age guests. As we all know, the nomadic Kyrgyz 
people lived in yurts, and the whole family slept in the same house. If there is a bride or an adult girl in the house, a curtain was drawn on one side of the yurt, and the bride undressed behind that curtain. A guest who came to the house of the Kyrgyz people, which was not without guests, also slept in that house. After a meal, it is necessary to prepare a place for a guest to sleep. In this time, the words, "Guests, get out and make the bed," is of course awkward and rude. That is why "Perform the ritual of the guest" was said figuratively and politely. "Kaada" is derived from the Arabic word "qagida", which means "rule, ritual". "Guest ritual" means to go out, rest, wash hands with face, emptying space for making a bed.

The famous satirist and Honored Artist of the Kyrgyz Republic Kumondor Abylov said in one of his concerts: "Kyrgyz people love their guests more than their children. Not eat the good luck food himself or not give it to his children, but he kept it for an unknown guest, and even invite the enemy to his feast." The Kyrgyz people have never asked why a guest came. These are peculiarities of the Kyrgyz tradition regarding hospitality. First, they did not ask the guest where he came from or where he is going. When the guest is leaving, they said, "It is respect to ask the name and it is Sunnah to ask for a word. It is our duty to know." Or the guest may simply explain and leave. Second, they slaughtered a sheep, lamb, or goat for the guest. Moreover, in the nomadic life of the Kyrgyz, who were engaged in animal farming, lived separately from each other on the pastures, wanted to be aware of the world, and wanted to communicate with others.

\section{Phraseological Unit Interpretations}

The Russian proverb "Милости прошу к нашему шалашу" (literally welcome to our hut) reflects the etiquette of the Russian people and the joy of welcoming a guest. This concept is very important in Russian culture, and at the same time, it means hospitality and warmth. The origin of this custom is well known. For hundreds of years, hospitality has been an integral part of the Russian people. In the past, Russians used to treat visitors with respect, especially strangers, and treat them well so that they would not be upset. Only then did they believe that a stranger would not harm them. They believed that sadness and anger create negative energy in a person. Today's tradition of welcoming delegations with bread and salt also means that a peace agreement will be reached.

There was a saying, "Хлеобосольство побеждает разбойников" (Bread and salt defeat the robber). Russian people were upset if guests are less. The host, his wife, and their children in front of the guest (if the guest was honored) said, "Taste a little more." When escorting the guest, they wished him a safe journey and said: "Скатертью дорога" which means a smooth journey. When escorting a guest, it was said "Конного гостя провожай до коня, а пешого до ворот", which means to escort equestrian guest to his horse, and pedestrian guest to gates.

The British like to be at home. They say, "My house is my castle," so they don't want their neighbors to know what's going on in their house. If you enter 
the English house for an hour, you will be offered a cup of tea. The British, like the Russians, drink a lot of tea. But unlike the Russians, the British prefer to drink tea with milk. And they drink coffee without milk, stronger. The guest hears a question or two from the English. "One lump or two?" or "Lemon or cream?" Such as The first question is how much sugar to add, and the second question is whether you choose lemon or sour cream. These questions can be answered as follows: "Coffee. No milk. Two sugars. Please (Coffee without milk, two sugars if possible) (Savenko, 2017).

In England, no one comes to visit without an invitation. They only go when they are invited. If they want to invite you, they will ask you if you can come to dinner on the first Sunday of the following month at six or seven o'clock. Don't go with your children unless they tell you to. If you are allergic to anything, you should tell the guest on the day of the invitation.

It is advisable to leave the guest early. English people also say that it is inappropriate for a guest to stay for a long time. "The best fish smell when they are three days old" means that the smell of fish that stays for a long time is unpleasant. As long as the guest stayed, it meant the same unpleasant. Russian people also say that it is not necessary to abuse hospitality. Sitting for a long period can lead to annoying and even waste of valuable time. After we have already said that the life of the Kyrgyz people is connected with animal farming, before we talk about the way of life in England, we are talking about the Kyrgyz phraseology “Алдына кырк жылкы айдоо" (Forty horses in front), which can be seen from the English equivalent of the same phraseology.

The phraseology "forty horses in front" means to get drunk. And the English equivalent of this meaning is "three sheets in the wind." The word-to-word translation of this phraseology is the three sails in the wind. The Kyrgyz people compare a drunk man to driving into the front forty horses, because a man who driving forty horses cannot walk straight, they associate necessity to drive horses altogether, walk along the back of each horse, not to allow horses walk out of the road when driving every horse.

The Anglo-Saxons compared this phraseology with the three sheets in the wind. When there is a wind at sea, the sails of the ship sway in the wind. The English people compare drunk men to the sails of a ship in the wind. From this comparison, it is clear that the way people live depends on where they live, and their outlook on life and worldview depends on it. Because England is a country surrounded by the British Peninsula, its lifestyle is closely connected with the sea.

In studying nature, plants are important in human life and activity. Forests on the Russian territory, a variety of plants used by people in agriculture and everyday life, have found their expressions in the phraseology. From ancient times, forests have been a source of life for Russian people, and collected mushrooms with vegetables were used as food. Almost everything is made from trees, spoons, and even buttons. Forest was also a place for hunting. Someone goes to the forest 
just to play, pick vegetables, or hunt, and someone goes to get woods. "Что-либо дремучий (темный) лес для кого-либо" means "What is either a timid (dark) forest or something; the lexeme “дремучий” means “dark” or “темный”, meaning thick and dark, the forest, which is untouched by sunlight and which is easy to lose in the darkness, is compared to a person who is unaware of things, phenomena, or even a vague, incomprehensible character.

The Kyrgyz, Russian, and English phraseology equivalents are shown in Figure 1. The phraseology "All at sea" literally means that there is nothing around but the sea. This phraseology means not knowing what to do. It is a situation in which there is no end to the land, and there is no end to the sea. The British associated this moment with the sea. It is hard to imagine a time when there is no ship or boat in the invisible sea. While the ship is intact, we will pray for more land. The same desperate situation is described by the Russian people, who use the phrase "как в лесу" (as in a forest). It is not easy for a lost person to find his way in the Russian forest. The Russian people, on the other hand, attribute this situation to be lost in a forest. Indeed, there have been times in their lives when they have been lost in the woods and have become desperate and do not know what to do.

All at sea is literally translated as the whole sea, быть в полном недоумении means to be completely immersed and do not understand anything at all, $B$ растерянности means to be lost or to lose oneself; “втупике; как в темном лесу" is equivalent meaning to staying in invisible forest. In English phraseology, it means a very dangerous situation, and not knowing what to do. In the Russian language, such a situation is associated with the dark forest.

We have already mentioned that phraseologies are not translated mostly; they only have equivalents that reflect their meanings in other languages. In the Kyrgyz language, the equivalent meaning “тепкирин таппай калуу” is expressed by the phraseology of not finding a key. The Kyrgyz word "tepkir" is derived from the Arabic word "takbir" (glorification of God) (Тепкиримди качырышты in the Russian phraseology means “они меня напугали” (they frightened me). There is a regular expression in the phraseology of not being able to find one's meaning, which also means falling out of one's mouth (not knowing what to do).

Another example follows "be in law water" for which literal translation is to

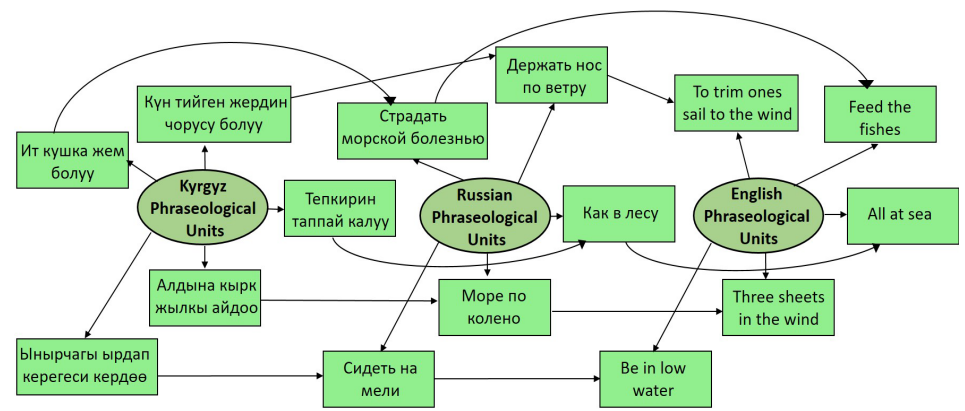

Figure 1. Phraseological units interpretations in the Kyrgyz, Russian and English languages. 
stay in shallow water. This constant expression means to be in a difficult financial situation without money. In the United Kingdom, if the seas are flooded and shallower, there will be less fish, less fish poisoning, and a negative impact on the economy. The Russian equivalent of this phraseology is to “сидеть на мели."

The word-to-word translation of this phraseology from the Russian language into the Kyrgyz language is the place where water flows. Here it is clear that fishing is also important for the Russian people. It has been suggested that the flooding could damage Russia's fishing grounds. The Kyrgyz equivalent is “ынырчагы ырдап, керегеси кердөө” (very poor, starving, and naked). In this regular expression, the phrase ынырчак is a saddle that is usually woven on to a bull, designed to carry the load.

"Kerege" is referred to side timbers made from wood, crossed with each other and fastened, square shaped, covered with felt outside (Akmataliev \& Baigaziev, 2015), which is associated with the Kyrgyz people farming and nomadic lifestyle.

The phraseology "To trim one's sail to the wind" literally means to put the sails in the wind. The presence of wind is essential for the ship, as the sails must move in the direction of the wind. The wind was blowing. Russian equivalent is “держать нос по ветру" (hold nose to the wind). This means placing the bow of a ship or boat in the direction of the wind, as wind is important for fishermen. The Kyrgyz phrase that expresses these meanings as “күн тийген жердин чорусу болуу" (to be a part of the sun), abbreviated from choru-chor (чору-чор), meaning a disabled woman (Yudakhin, 2000). For nomadic Kyrgyz people, exposure to the sun was a great achievement. It was not easy for the people to move their yurts on a camel or a horse, and their belongings on another horse, when it was raining. As a result, the concepts sun shining and reverse developed.

Feed the fishes is literally means feed the fish i.e. be food for the fish. The Russian equivalent of this regular expression is 1) to drown 2) to suffer from seasickness. The Kyrgyz equivalent is to be eaten by dogs and birds, to die in the field, and to remain in the field without being buried. It is not surprising that the phrases in these three languages, which have the same meaning, are related to the worldview of these peoples. The British said that because of the high level of fishing in the high seas, they died in a sudden storm while at sea, and the fish were found dead in the sea. The Russian people also associated this phenomenon with the sea. Because, as we have said, the way of life of the Russian people is multifaceted, because the vast territory of Russia has many areas connected with the plains, endless forests, and even mountains and the sea.

Страдать морской болезнью (suffering from seasickness). This is a constant phrase, which means getting sick with seasickness. If the ship is swaying at sea, it makes a person feel dizzy. A person suffering from this disease needs to get to land immediately. This constant expression is reflected in the fact that if it does not reach land sooner, it can weaken the disease and lead to death.

Paremias are the most important ethnic memory of the people. The structure, composition, lexical meaning of paremias, comparisons, contrasts are reflecting 
the mentality of people, their image of life, morality, cultural values, and much more (Madmarova, 2016).

\section{Conclusion}

In conclusion, the phraseological structure of language is unique, and considered as a mirror that reflects the worldview, mentality, historical and cultural aspects of the linguocultural society. It is clear from the above examples compared the regular expressions equivalent to the people worldview, their outlook on life, and associations. Language is illustrating that humankind is an integral part of the environment. In this study, the equivalents and meanings of idioms were analyzed and compared. At the same time, we are convinced that phraseology is a unique branch of humankind's history and life experiences. Phraseological units are widely used in a daily life, as they are reflecting nation mentality, thinking style and linguistic tools in the Kyrgyz, Russian and English languages.

\section{Conflicts of Interest}

The authors declare no conflicts of interest regarding the publication of this paper.

\section{References}

Akmataliev, A. A., \& Baigaziev, S. O. (2015). Explanatory Dictionary of the Kyrgyz Language $(800$ p). Bishkek: Eurasia Press.

Azizova, F. S., Ashurova, F. L., Abramova, N. T., \& Djabbarova, K. A. (2020). Teaching English Phraseological Units to Linguistic University Students. Journal of Critical Reviews, 7, 671-674. https://doi.org/10.31838/jcr.07.05.137

Beshaj, L. (2014). Motivation and Etymology of Phraseological Units in English and Albanian Language. Mediterranean Journal of Social Sciences, 5, 189.

http://dx.doi.org/10.5901/mjss.2014.v5n1p189

Gablasova, D., Brezina, V., \& McEnery, T. (2017). Collocations in Corpus-Based Language Learning Research: Identifying, Comparing, and Interpreting the Evidence. Language Learning, 67, 155-179.

Israilova, A. M. (2017). Phraseologisms in the Kyrgyz language. Science, New Technologies and Innovations of Kyrgyzstan, 1, 211-213.

Ivanova, M. (2018). Reflection of Russian National Culture in Phraseology. Master's Work, Turku: Turku University.

Kremmel, B., Brunfaut, T., \& Alderson, J. C. (2017). Exploring the Role of Phraseological Knowledge in Foreign Language Reading. Applied Linguistics, 38, 848-870.

Madmarova, G. A. (2016). Reflection in the Language of National-Specific Characteristics of the People. Economics and Society, 1, 605-610.

Nikulina, E.A. (2017). English Phraseology in Russian Linguistics: Research Vectors. Teacher of the XXI Century, No. 4-2, 348-354.

Pym, A. (2014). Charles Bally and the Origins of Translational Equivalence. International Journal of Interpretation and Translation, 12, 45-63.

https://doi.org/10.1075/forum.12.2.03pym

Savenko, V. V. (2017). Culture and Traditions of English Hospitality. Chelyabinsk. 
Seydakmatov, K. (1988). Short Etymological Dictionary of the Kyrgyz Language. Frunze: Ilim Group.

Vrbinc, A., \& Vrbinc, M. (2014). Phraseological Units with Onomastic Components: The Case of English and Slovene. Revista de Lingüística Teórica y Aplicada, 52, 133-153. http://dx.doi.org/10.4067/S0718-48832014000100007

Yudakhin, K. (2000). To the Russian-Kyrgyz Dictionary (990 p.). Bishkek: Sham Publishing House.

Zhaparov, S., Konkobaev, K., \& Osmonova, Z. (2015). Phraseological Dictionary of The Kyrgyz Language (789 p). Bishkek. 